\title{
Publisher Correction: Alteration in Fluidity of Cell Plasma Membrane in Huntington Disease Revealed by Spectral Phasor Analysis
}

Sara Sameni ${ }^{1,2}$, Leonel Malacrida ${ }^{1,2,3}$, Zhiqun $\operatorname{Tan}^{4}$ \& Michelle A. Digman ${ }^{1,2}$

Correction to: Scientific Reports https://doi.org/10.1038/s41598-018-19160-0, published online 15 January 2018

The Supplementary Figures were omitted from the original version of this Article. This has been corrected in the PDF and HTML versions of the Article.

(i) Open Access This article is licensed under a Creative Commons Attribution 4.0 International C. License, which permits use, sharing, adaptation, distribution and reproduction in any medium or format, as long as you give appropriate credit to the original author(s) and the source, provide a link to the Creative Commons license, and indicate if changes were made. The images or other third party material in this article are included in the article's Creative Commons license, unless indicated otherwise in a credit line to the material. If material is not included in the article's Creative Commons license and your intended use is not permitted by statutory regulation or exceeds the permitted use, you will need to obtain permission directly from the copyright holder. To view a copy of this license, visit http://creativecommons.org/licenses/by/4.0/.

(c) The Author(s) 2018

${ }^{1}$ Laboratory for Fluorescence Dynamics, University of California Irvine, Irvine, CA, USA. ${ }^{2}$ Department of Biomedical Engineering, University of California Irvine, Irvine, CA, USA. ${ }^{3}$ Departamento de Fisiopatología, Hospital de Clinicas, Facultad de Medicina, Universidad de la República, Montevideo, Uruguay. ${ }^{4}$ Institute for Memory Impairments and Neurological Disorders, University of California Irvine, Irvine, USA. Correspondence and requests for materials should be addressed to M.A.D. (email: mdigman@uci.edu) 